\title{
PREDICTING THE SUMMER TEMPERATURE OF SMALL STREAMS IN SOUTHWESTERN WISCONSIN ${ }^{1}$
}

\author{
Stephen J. Gaffield, Kenneth W. Potter, and Lizhu Wang ${ }^{2}$
}

\begin{abstract}
One of the biggest challenges in managing cold water streams in the Midwest is understanding how stream temperature is controlled by the complex interactions among meteorologic processes, channel geometry, and ground water inflow. Inflow of cold ground water, shade provided by riparian vegetation, and channel width are the most important factors controlling summer stream temperatures. A simple screening model was used to quantitatively evaluate the importance of these factors and guide management decisions. The model uses an analytical solution to the heat transport equation to predict steady-state temperature throughout a stream reach. The model matches field data from four streams in southwestern Wisconsin quite well (typically within $1^{\circ} \mathrm{C}$ ) and helps explain the observed warming and cooling trends along each stream reach. The distribution of ground water inflow throughout a stream reach has an important influence on stream temperature, and springs are especially effective at providing thermal refuge for fish. Although simple, this model provides insight into the importance of ground water and the impact different management strategies, such as planting trees to increase shade, may have on summer stream temperature.

(KEY TERMS: stream temperature; modeling; watershed management; ground water hydrology; meteorology/climatology; surface water hydrology.)
\end{abstract}

Gaffield, Stephen J., Kenneth W. Potter, and Lizhu Wang, 2005. Predicting the Summer Temperature of Small Streams in Southwestern Wisconsin. Journal of the American Water Resources Association (JAWRA) 41(1):25-36.

\section{INTRODUCTION}

\section{Importance}

One of the most difficult challenges in managing cold water stream fisheries is understanding the controls of summer water temperature. Water temperature affects physiological processes and the distribution of aquatic species, and it limits productivity and the rates of important biochemical processes (Dunne and Leopold, 1978; Diana 1995). The distribution of brook trout (Salvelinus fontinalis) and brown trout (Salmo trutta) in Midwestern streams is typically limited by stream temperature (Becker, 1983). It is widely recognized that streams in this region are cooled by inflows of cold ground water (Becker, 1983; Bowlby and Roff, 1986; Meisner et al., 1988; Field and Graczyk, 1990; Meisner, 1990; McRae and Edwards, 1994; Poff and Allan, 1995; Seelbach and Wiley, 1997; Seelbach et al., 1997; Younus et al., 2000; Poole and Berman, 2001). However, shade from streamside vegetation, stream channel geometry, and weather conditions also have an important impact on stream temperature (Younus et al., 2000; Poole and Berman, 2001; Blann et al., 2001). A lack of understanding of the details of how these factors control summer water temperature in small Midwestern streams makes habitat management decisions difficult.

It is widely accepted that springs and other areas of concentrated ground water discharge create cold refuges for fish during the summer. Field surveys of small streams in the Sierra Nevada Mountains (Constantz, 1998) and Wisconsin (McRae and Edwards, 1994) have shown a correspondence between high rates of ground water discharge and cold summer stream temperature. However, little quantitative information is available about how the spatial distribution of ground water inflow affects stream temperature. Many previous studies have focused on heat

\footnotetext{
1Paper No. 02127 of the Journal of the American Water Resources Association (JAWRA) (Copyright @ 2005). Discussions are open until August 1, 2005.

2Respectively, Senior Hydrologist, Montgomery Associates: Resource Solutions, LLC, 2820 Walton Commons West, Suite 135, Madison, WI 53718; Professor, Department of Civil and Environmental Engineering, University of Wisconsin-Madison, 1415 Engineering Drive, Madison, Wisconsin 53706-1691; and Supervisory Research Biologist, Michigan Department of Natural Resources, Institute for Fisheries Research, 1109 North University Drive, Ann Arbor, Michigan 48109 (E-Mail/Gaffield: steve@ma-rs.org).
} 
transport in reservoirs and large rivers, where ground water discharge is likely to be very small compared to stream flow and have little impact on surface water temperature (Delay and Seaders, 1966; Sinokrot and Stefan, 1993; Lowney, 2000; Andradottir and Nepf, $2000 \mathrm{a}, \mathrm{b})$. Younus et al. (2000) demonstrated the importance of ground water discharge through simulations of daily and hourly variations in the temperature of a small Indiana stream, but they did not investigate the impact of spatial variations in ground water discharge within a stream reach.

\section{Objectives and Scope}

The goals of this study were to evaluate the key controls over the summer temperature of small streams in southwestern Wisconsin, including the impact of the rate and distribution of ground water inflow, and to test a practical model to guide watershed management decisions. Because most watershed managers lack the necessary time, resources, and expertise to use highly sophisticated models developed for research applications, a simple model requiring easily obtainable data was used.

The approach involved applying a mathematical model of heat transport to several streams and collecting field data to verify its accuracy. The method of the Stream Network Temperature Model (SNTEMP) (Theuer et al., 1984), a model for simulating complex networks of streams, was adapted to a spreadsheet program designed to simulate complex distributions of ground water discharge and shade along a single stream reach. Many watershed management applications can be addressed using SSTEMP (Bartholow, 2002), a simplified version of SNTEMP that simulates temperature in a stream segment with uniform conditions (available from the U.S. Geological Survey). The model was used to predict mean stream temperature during the hottest seven consecutive days of the summer, which is widely considered to be a critical period for cold water fish. However, the model is not limited to this approach and can be used to predict temperature during any period of interest. Although the model does not predict daily maximum temperature, understanding the controls over mean temperature provides insight into the behavior of maximum temperature. With adjustment of the model input parameters, it can be applied to similar streams in other geographic areas and to different times of year.

\section{Physical Setting}

This study focused on four streams in the unglaciated "Driftless Area" of southwestern Wisconsin: Warner Branch, Warner Creek, Joos Creek, and Eagle Creek (Figure 1). These watersheds have well developed stream networks that cut 100 meters or more into approximately horizontal layers of dolomite and sandstone. Streamflow in this region is generated primarily by shallow ground water flow systems supplied by nearby recharge areas (Gaffield et al., 1998; Young, 1992; Zaporozec and Cotter, 1985). Ground water inflow to streams is concentrated at springs in some locations and occurs as diffuse seepage in others, depending on the character of the underlying bedrock.

The Driftless Area has a high concentration of cold water streams that support both brook trout (Salvelinus fontinalis) and brown trout (Salmo trutta) and have long been valued for recreational fishing (Becker, 1983). Agricultural development, beginning in about 1850, severely impacted streams by increasing soil erosion, runoff, and peak flows (Johnson, 1976), resulting in decreased ground water recharge and base flow (Potter, 1991). Consequently, the trout fishery was dramatically reduced by the middle of the 1900s (Scott and Hoveland, 1951). Although the watershed is still dominated by agriculture, these trends have reversed over the past few decades (Kent, 1999; Trimble and Lund, 1982), probably due to improvements in land management practices (Sampson, 1981; Potter, 1991). Today, many Driftless Area watersheds provide suitable habitat for trout, and maintaining and improving the quality of the fishery is an important management objective.

\section{MODEL DESCRIPTION}

The model simulates spatial temperature variations at the stream reach scale following the approach of Theuer et al. (1984), and it evaluates the competing effects of atmospheric interactions and ground water inflow. It represents steady-state conditions, so it approximates mean water temperature and applies to dry weather periods when stream flow is nearly constant. The model simulates downstream flow in one dimension, relying on the assumption that streams are well mixed, with no transverse or vertical gradients in temperature (i.e., it ignores diffusion and mechanical dispersion). This assumption is valid for small streams that are dominated by downstream advective transport, such as the ones in this study (Chapra, 1997; Gaffield 2000). 

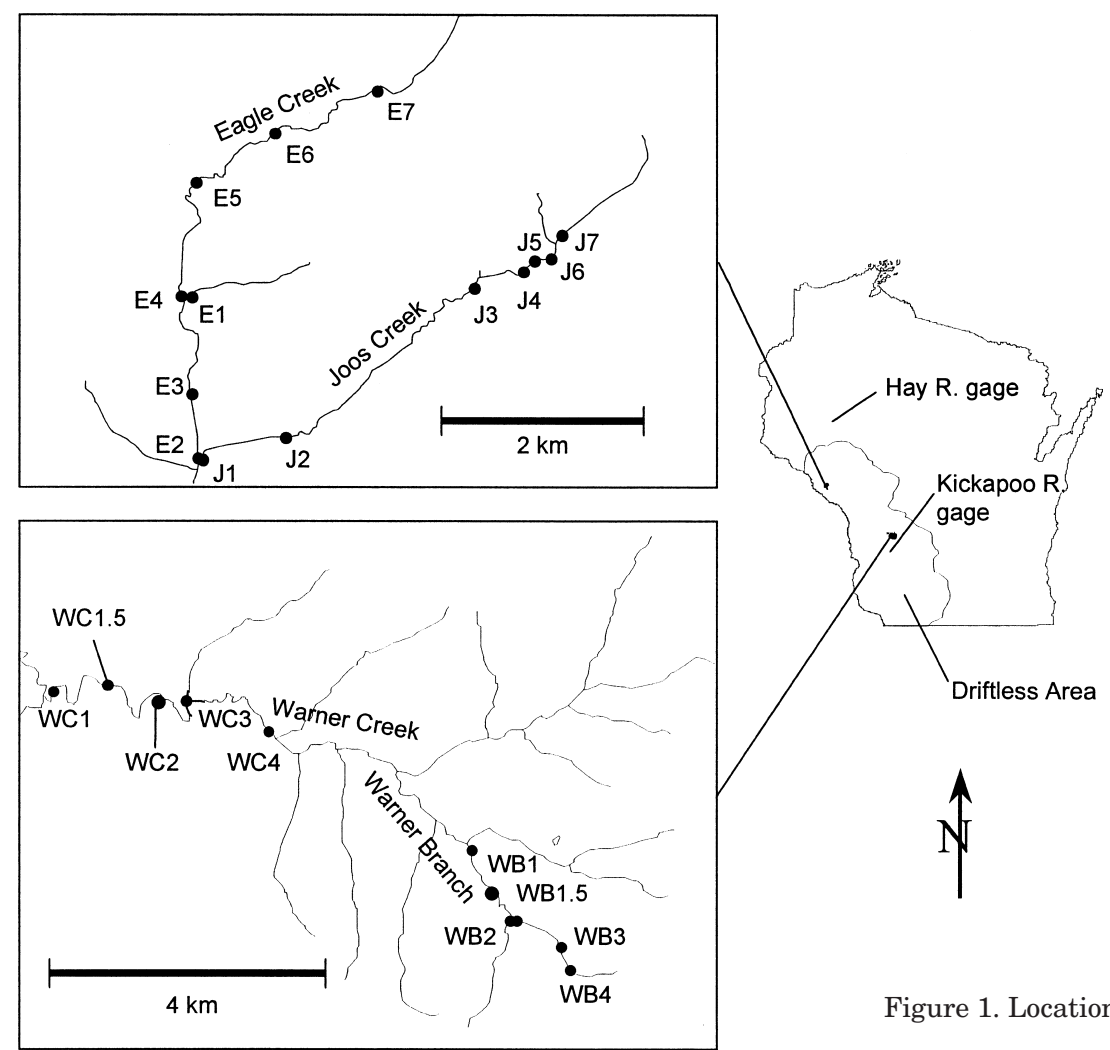

Figure 1. Location of Study Streams and Monitoring Stations.

Atmospheric impacts on water temperature are represented in the model by the simple equilibrium temperature approximation. The net energy flux, $\mathrm{S}_{\mathrm{n}}$ $\left(\mathrm{W} / \mathrm{m}^{2}\right)$, to the stream is written

$$
\mathrm{S}_{\mathrm{n}}=\mathrm{H} \rho \mathrm{c}_{\mathrm{p}}\left(\mathrm{T}_{\mathrm{eq}}-\mathrm{T}\right)
$$

The equilibrium temperature, $\mathrm{T}_{\mathrm{eq}}\left({ }^{\circ} \mathrm{C}\right)$, is the theoretical temperature that the water would reach under constant meteorologic and geomorphic conditions and with no ground water discharge. The constant, $\mathrm{H}$ $(\mathrm{m} / \mathrm{s})$, describes the rate at which the stream temperature, $\mathrm{T}\left({ }^{\circ} \mathrm{C}\right)$, approaches the equilibrium temperature, $\rho$ is the density of water $\left(\mathrm{kg} / \mathrm{m}^{3}\right)$, and $\mathrm{c}_{\mathrm{p}}$ is the specific heat of water $\left(\mathrm{J} / \mathrm{kg} /{ }^{\circ} \mathrm{C}\right) . \mathrm{T}_{\text {eq }}$ and $\mathrm{H}$ were estimated for the hottest seven-day period in 1999 using the method described by Theurer et al. (1984), using field measurements of solar radiation and air temperature and standard approximations for evaporation, convection, long wave radiation, and streambed conduction. Details are included in the Appendix. Both $\mathrm{T}_{\text {eq }}$ and $\mathrm{H}$ depend on the fraction of the stream surface shaded by vegetation (Table 1 ).

Ground water inflow rates were estimated based on measurements of stream flow at different stream locations. Streamflow was assumed to increase linearly between measurement locations, which is reasonable for closely spaced measurements (such as every 1,000 $\mathrm{m}$, or less in the headwaters). Streamflow, $\mathrm{Q}\left(\mathrm{m}^{3} / \mathrm{s}\right)$, between measurement locations is represented by

$$
\mathrm{Q}=\mathrm{a}+\mathrm{bx}
$$

where $a$ is the upstream discharge $\left(\mathrm{m}^{3} / \mathrm{s}\right), \mathrm{b}$ is the ground water inflow rate per unit length of stream channel $\left(\mathrm{m}^{2} / \mathrm{s}\right)$, and $\mathrm{x}$ is the downstream distance $(\mathrm{m})$.

TABLE 1. Estimated Parameter Values for Model Calculation of Heat Flux From Meteorological Processes.

\begin{tabular}{ccc}
\hline $\begin{array}{c}\text { Shaded } \\
\text { Fraction }\end{array}$ & $\begin{array}{c}\text { Equilibrium } \\
\text { Temperature } \\
\mathbf{T}_{\mathbf{e q}}\left({ }^{\circ} \mathbf{C}\right)\end{array}$ & $\begin{array}{c}\text { Heat Exchange } \\
\text { Constant } \\
\mathbf{H}\left(\mathbf{m} / \mathbf{s ~ x ~ 1 0} \mathbf{~ 1 0}^{-5}\right)\end{array}$ \\
\hline 0.0 & 29.1 & 1.19 \\
0.1 & 28.6 & 1.17 \\
0.2 & 28.0 & 1.14 \\
0.3 & 27.5 & 1.12 \\
0.4 & 26.9 & 1.09 \\
0.5 & 26.4 & 1.07 \\
0.6 & 25.8 & 1.05 \\
0.7 & 25.2 & 1.02 \\
0.8 & 24.6 & 1.00 \\
0.9 & 24.0 & 0.978 \\
1.0 & 23.3 & 0.955 \\
\hline
\end{tabular}


Stream temperature, $\mathrm{T}\left({ }^{\circ} \mathrm{C}\right)$, is computed using the heat transport Equation (3) (e.g., Chapra ,1997; Fischer et al., 1979)

$$
\mathrm{bT}+(\mathrm{a}+\mathrm{bx}) \frac{\mathrm{dT}}{\mathrm{dx}}=\mathrm{T}_{\mathrm{gw}} \mathrm{b}+\mathrm{WH}\left(\mathrm{T}_{\mathrm{eq}}-\mathrm{T}\right)
$$

for constant ground water temperature, $\mathrm{T}_{\mathrm{gw}}\left({ }^{\circ} \mathrm{C}\right)$, and stream channel width, W (m). The left side of the equation describes downstream transport, and the right side represents ground water inflow and meteorologic interactions. The analytical solution for Equation (3) has the form

$\mathrm{T}=\frac{1}{\phi+1}\left[\mathrm{~T}_{\mathrm{gw}}+\mathrm{T}_{\mathrm{eq}} \phi+\left(1+\frac{\mathrm{bx}}{\mathrm{a}}\right)^{-(1+\phi)}\left(\mathrm{T}_{0}[1+\phi]-\mathrm{T}_{\mathrm{gw}}-\mathrm{T}_{\mathrm{eq}} \phi\right)\right]$

where

$$
\phi=\frac{\mathrm{W} \mathrm{H}}{\mathrm{b}}
$$

and $\mathrm{T}_{0}$ is the upstream water temperature $\left({ }^{\circ} \mathrm{C}\right)$.

For a stream with constant discharge $(b=0)$, Equation (4) is undefined. The solution for this case is found by taking the limit of Equation (4) as b approaches zero.

$$
\mathrm{T}=\mathrm{T}_{\mathrm{eq}}+\left(\mathrm{T}_{0}-\mathrm{T}_{\mathrm{eq}}\right) \exp \left(-\frac{\mathrm{WHx}}{\mathrm{a}}\right)
$$

In practice, it is unlikely that a stream reach will have no net gain or loss of ground water; however, Equation (6) is useful to illustrate theoretical relationships. In this study, temperature was calculated at $50 \mathrm{~m}$ intervals along the length of the stream reaches.

\section{MODEL CALIBRATION AND VERIFICATION}

\section{Data Collection}

Electronic thermographs placed at several locations in each stream recorded water temperature every 30 minutes from May to September 1999 (Figure 1). These data showed that the seven consecutive days with the warmest water temperatures occurred from July 24 to 30 . Then, the corresponding seven-day mean temperatures were calculated for each thermograph location. The assumption that water in the channel was well mixed was then tested by monitoring for vertical and horizontal temperature variations at one channel cross section (WC1.5). The spatial variation in temperature measured by four thermographs placed at different depths and horizontal positions was approximately $0.5^{\circ} \mathrm{C}$, which is nearly the same as the precision of the thermographs $\left(0.4^{\circ} \mathrm{C}\right)$. Measurements with a hand-held thermometer at several arbitrarily chosen locations also failed to detect lateral or vertical variations.

Water temperature was monitored at several springs to determine the mean ground water temperature during the study period. Although ground water at depths of 10 to $20 \mathrm{~m}$ typically has a stable temperature of 1 to $2^{\circ} \mathrm{C}$ above the local mean annual air temperature, the temperature of very shallow ground water can vary substantially during a year (Domenico and Schwartz, 1990).

Meteorologic conditions during the hottest seven days were determined through a combination of field measurements and data from nearby weather stations. Solar radiation and air temperature were monitored at 30-minute intervals at one location in the Warner Branch watershed and a second location in the Eagle Creek watershed. Other meteorologic data, including dew point temperature, wind speed, cloud cover, and atmospheric pressure were obtained from National Weather Service stations in LaCrosse and Madison, Wisconsin.

Ground water inflow rates to the streams were determined indirectly by measuring stream flow at each thermograph location (Figure 1). Measurement dates during dry periods were chosen to ensure that ground water inflow was the only source of water in the streams. The discharge of each stream was measured twice during spring and summer 1999, with each survey completed in one day to minimize variability caused by changes in stream flow during the survey period. Flow measurement dates for three of the surveys were at least five days after the most recent high flow event recorded by nearby stream gages. The spring date for Joos and Eagle Creeks was two days after a small high flow event. Discharge was measured with Price "mini" current meters using the standard wading technique of the U. S. Geological Survey (Buchanan and Somers, 1969).

Because no direct measurements of streamflow were done during the period from July 24 to 30 when the mean seven-day water temperature was calculated, streamflow was estimated using an indexing method (Potter, 2001; Potter and Gaffield, 2001). For each of the survey sites, the ratio of the measured flow to the concurrent flow at a nearby continuous stream gaging station was computed. This ratio was multiplied by the flow at the gaging station between July 24 and 30 to estimate flow at each of the sites 
during this period. Warner Branch and Warner Creek were indexed with the Kickapoo River gaging station at LaFarge, Wisconsin, and the gaging station on the Hay River at Wheeler, Wisconsin, was used to index Joos and Eagle Creeks (Figure 1). The lack of precision in these base flow estimates may lead to some errors in the simulated temperatures; however, the index method is effective for identifying spatial trends in ground water inflow to Driftless Area streams (Potter and Gaffield, 2001), which is the primary focus of this study.

Riparian vegetation was described qualitatively, identifying stream reaches with fairly homogeneous vegetation cover separated by major transitions in vegetation. Field observations were supplemented with analysis of aerial photographs. Descriptive categories included forest, open woodland, wooded buffer, ungrazed grass, and grazed grass.

\section{Model Setup}

Because the model assumes that the stream width, shade, and ground water inflow rate are constant, it was necessary to divide each stream reach that was modeled into several subreaches with approximately uniform conditions. The boundaries between subreaches were defined to coincide with the locations of base flow measurements and major changes in riparian vegetation. Field data from the thermograph located farthest upstream were used to define the input temperature, $\mathrm{T}_{0}$, for the first subreach. The temperature simulated at the downstream end of each subreach was used as the input temperature for the next subreach downstream. This discretization of subreaches resulted in artificially abrupt changes in conditions from one subreach to another, and this should be kept in mind when interpreting the results.

\section{Model Calibration}

Data from Warner Branch and Joos Creek were used to fine tune the model to match late summer conditions. In a model calibration process, input parameters that are not known with certainty are adjusted within reasonable ranges to produce the "best fit" between the simulated and observed values. The calibration procedure was used to determine values for the shade provided by each vegetation type because, unlike base flow or meteorologic conditions, there were no accurate measurements or estimates for these values. All other parameters were held constant. Starting with initial guesses of 0.5 for all of the fractional shade values, the shade values were adjusted for each vegetation type by trial and error until the simulated temperatures most closely matched the measured temperatures. It was assumed that shade decreased by vegetation type in the following order: forest, wooded buffer, open woodland or ungrazed grass, and grazed grass.

It was necessary to use data from two streams for the calibration because no single stream had all of the vegetation categories that were described. First, data from Warner Branch were used to determine shade values for every type of vegetation except ungrazed pasture and grass buffers. Then, the shade values were calibrated for these two vegetation categories for Joos Creek (Table 2).

TABLE 2. Calibrated Values for Fraction of Stream Surface Shaded by Each Vegetation Type.

\begin{tabular}{lc}
\hline Vegetation Type & Shaded Fraction \\
\hline Forest & 0.8 \\
Wooded Buffer & 0.7 \\
Open Woodland & 0.4 \\
Ungrazed Grass & 0.3 \\
Grazed Grass & 0.2 \\
\hline
\end{tabular}

The calibrated model matched the measured sevenday temperatures for Warner Branch and Joos Creek very closely (Figures 2 and 3). Differences between the simulated and measured temperatures are less than $0.5^{\circ} \mathrm{C}$ for Warner Branch (Figure 2a) and at most, $1.0^{\circ} \mathrm{C}$ for Joos Creek (Figure $2 \mathrm{~b}$ ). Perhaps equally important is the fact that the model reproduces the downstream warming and cooling trends indicated by the data for both streams. The cooling below 2,500 m in Warner Branch appears to be related to an increase in shade, because the ground water inflow rate and stream width here appear to be similar to other parts of the reach. However, high rates of ground water inflow appear to cause the cooling in the headwaters of Joos Creek, where the width and vegetation are fairly uniform.

\section{Model Verification}

A calibrated model solution is not necessarily the only one that can provide a satisfactory match to the measured values; other combinations of parameter values may work equally well. To gain confidence that the shade values determined in the calibration process are truly representative of summer conditions for small Driftless Area streams, the calibrated model 
was tested on two additional streams: Warner and Eagle Creeks. The same procedure was followed as for Warner Branch and Joos Creek, except that shade parameters were fixed at the calibration values.

The calibrated model performed reasonably well for Warner and Eagle Creeks. Simulated temperatures for Warner Creek are within $1^{\circ} \mathrm{C}$ of the measured temperatures (Figure 2c). For Eagle Creek, the modeled temperatures are as much as $3.6^{\circ} \mathrm{C}$ too warm in the headwaters, but they are within $1.5^{\circ} \mathrm{C}$ of the measured temperatures in the downstream part of the modeled reach (Figure $2 \mathrm{~d}$ ). The model generally matches the shape of the temperature profile for Eagle Creek, with rapid warming in the headwaters and downstream cooling in the lower half of the

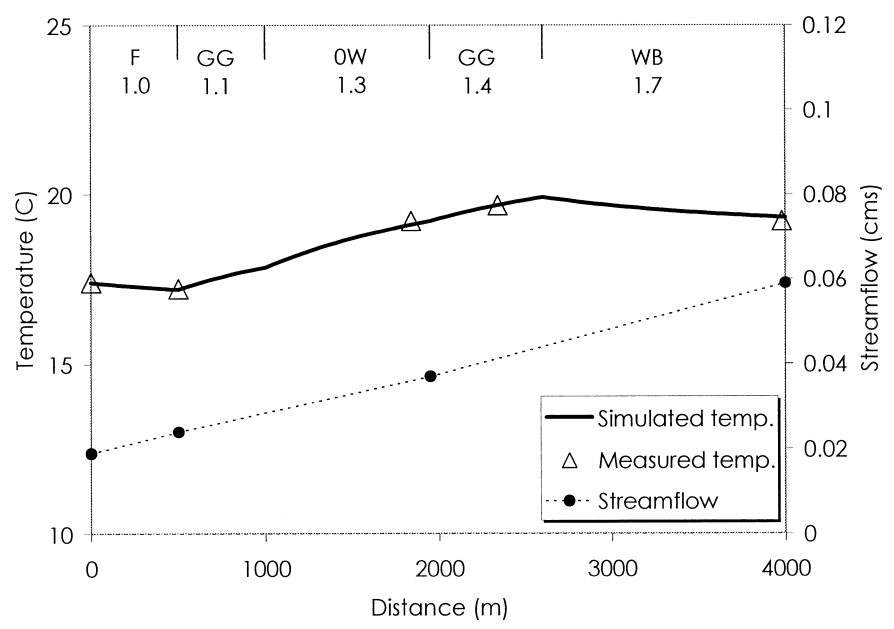

(a)

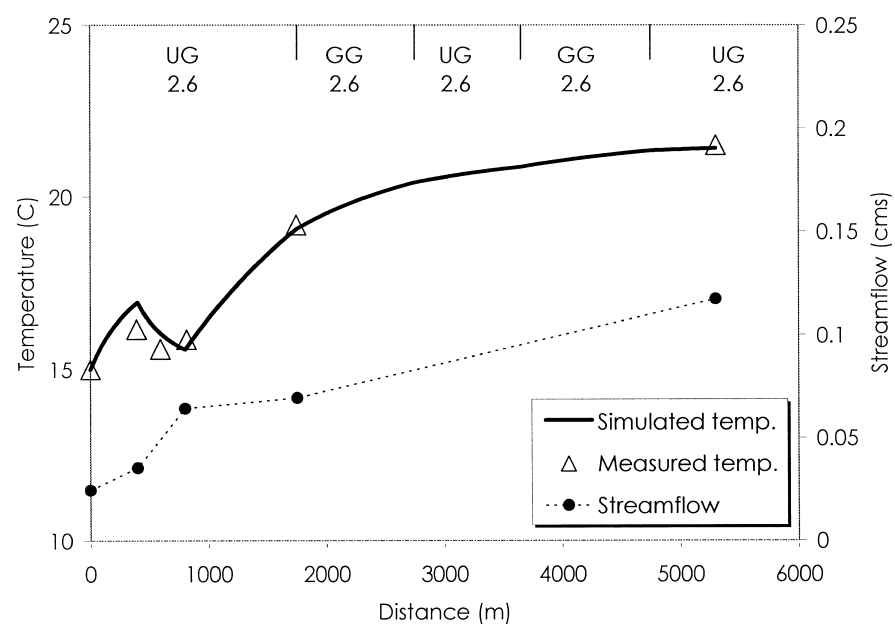

(b) reach. This cooling appears to be caused by an increase in ground water inputs, because channel width and riparian vegetation do not change substantially in that area. The model error in the headwaters of Eagle Creek is likely due to insufficient resolution in the measurement of stream base flow; the first two measurements are separated by $2,500 \mathrm{~m}$.

\section{BASIC RELATIONSHIPS}

The model is useful for testing the sensitivity of summer stream temperature to changing conditions. One method for illustrating the impact of many

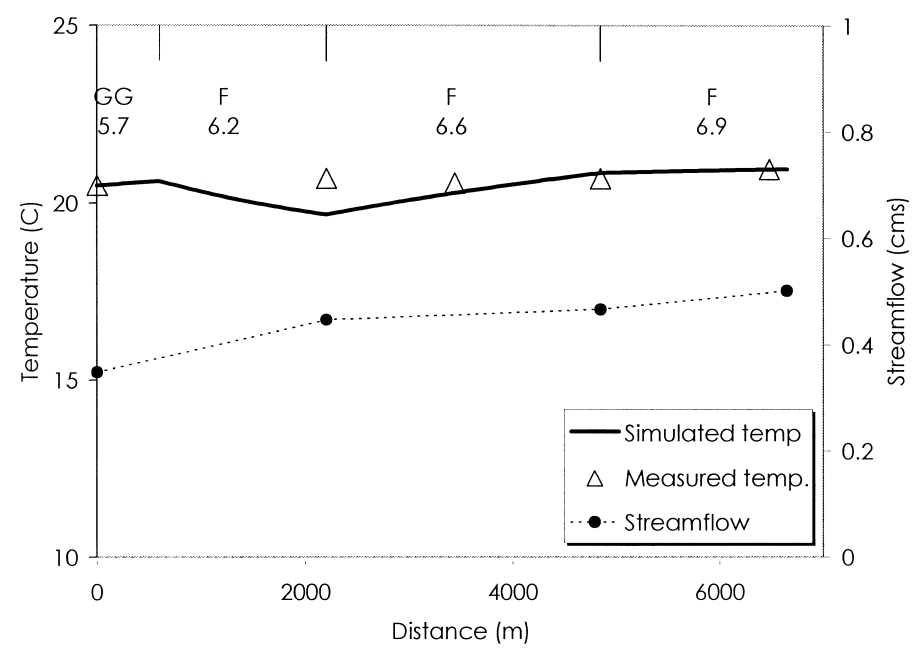

(c)

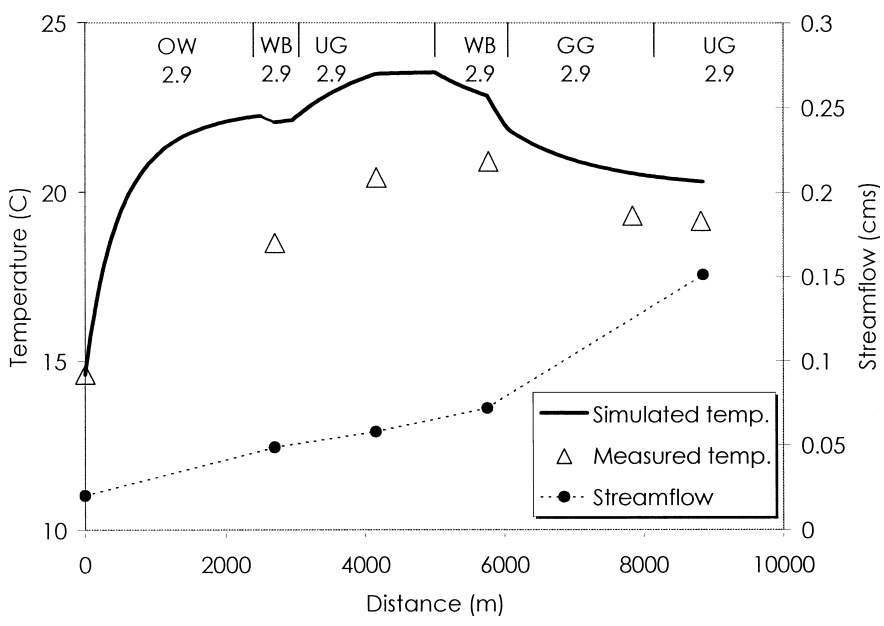

(d)

Figure 2. Comparison of Temperatures Simulated (solid lines) and Measured (points) for Model Calibration for (a) Warner Branch and (b) Joos Creek, and Model Verification for (c) Warner Creek and (d) Eagle Creek. Measured streamflow shown in cubic meters per second. Streamside vegetation and channel width in meters shown at top of plot ( $F$ is forest, OW is open woodland, WB is wooded buffer, UG is ungrazed grass, and GG is grazed grass). 
different combinations of model input parameters is to generate a dimensionless plot of model simulations (Figure 3). The new dependent variable is the stream temperature, $\mathrm{T}$, divided by the ground water temperature, $\mathrm{T}_{\mathrm{gw}}$. The independent variable, bx/a, represents distance downstream, $\mathrm{x}$, relative to the upstream discharge, a, and streamflow gain rate, b. Each curve represents a different set of possible meteorologic and ground water inflow conditions, indicated by the ratio $\mathrm{WH} / \mathrm{b}$. High values indicate a large stream width, W, or large thermal exchange coefficient, $\mathrm{H}$ (caused by lack of shade). Low values of $\mathrm{WH} / \mathrm{b}$ indicate relatively rapid increases in streamflow (large value for $b$ ).

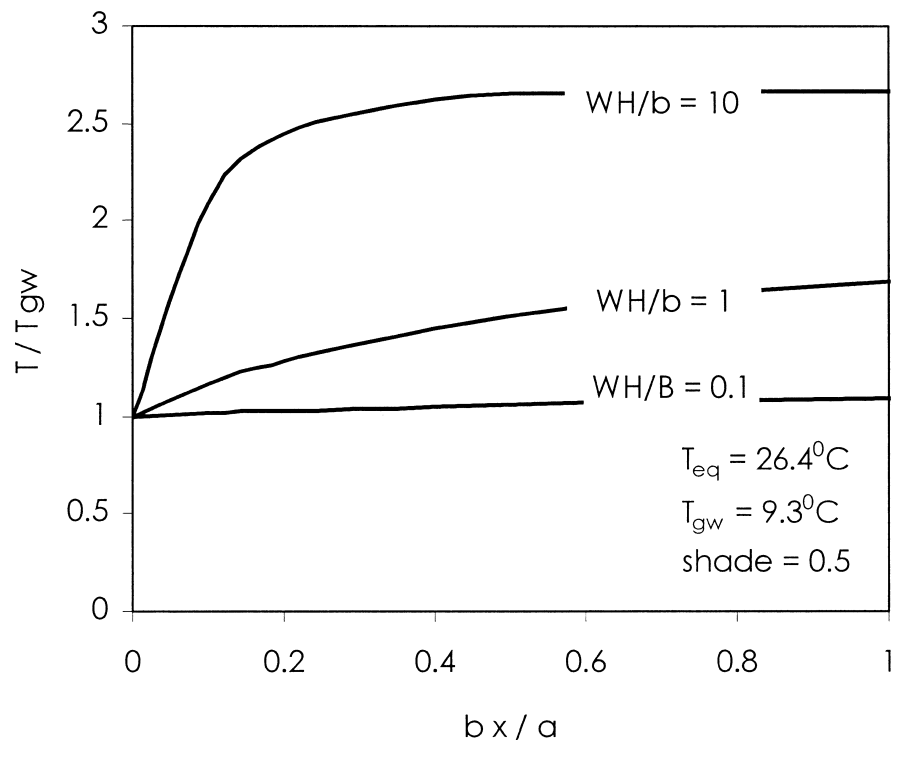

Figure 3. Dimensionless Plot of Simulated Stream Temperature Showing the Impact of Changes in Width and Ground Water Inflow Rate. Plot represents late summer weather conditions and 50 percent shading of the stream surface.

The model indicates that stream temperature is very sensitive to changes in channel width and ground water inflow rates (Figure 3). For the streams in this study, $\mathrm{WH} / \mathrm{b}$ varied over approximately two orders of magnitude, presumably due to changes in width and ground water discharge rates. Changing geomorphic conditions over time or with distance downstream can cause stream channel width to change by more than 100 percent (Allmendinger et al., 2000; Johnson, 1976), and ground water discharge rates also vary widely. By contrast, the heat exchange coefficient, $\mathrm{H}$, varies by only approximately 25 percent between full sun and full shade conditions (Table 1).

Stream temperature is bounded by the ground water temperature and the equilibrium temperature (Figure 3). Where the heat flux from meteorologic processes are much greater than for ground water inflow ( $\mathrm{WH} / \mathrm{b}$ is large), the stream temperature approaches the equilibrium temperature. If ground water inflow dominates $(\mathrm{WH} / \mathrm{b}$ is small), the stream temperature approaches the ground water temperature. The distance required for the temperature to stabilize depends on the size of the stream; the larger the upstream discharge, a, the greater the distance, $\mathrm{x}$, that is required to reach conditions represented by the right side of Figure 3.

The model also demonstrates the importance of springs. Consider a small stream with uniform shade along its entire length and an upstream discharge of $0.05 \mathrm{~m}^{3} / \mathrm{s}$ that experiences a 50 percent increase in streamflow through a zone of ground water inflow (Figure 4). The length of this ground water inflow zone has a substantial impact on the amount of cooling that is produced. The lowest water temperatures are generated where all of the ground water inflow is concentrated along a very short length of the stream (e.g., from a spring). This cooling effect is very local, and the stream warms rapidly downstream. If the same ground water inflow is spread uniformly over longer sections of the stream (e.g., as diffuse seepage rather than discharge from a spring), the water temperature drops by progressively smaller amounts. Notice, however, diffuse ground water discharge creates the lowest temperature at the downstream end of the reach. This illustrates the tradeoff between diffuse and concentrated ground water inflow. Concentrated inflow produces the most cooling, but its impact does not persist very far downstream; diffuse inflow has a smaller cooling effect but can moderate temperature over longer stream reaches.

\section{MODEL APPLICATION}

The model was used to test the sensitivity of the temperature of Joos Creek to changes in shade, channel width, and base flow, factors that are affected by management of the riparian zone and land use throughout the watershed. Brook trout thrive in the upper $1,000 \mathrm{~m}$ of the study reach where the water is relatively cold (Figure $2 \mathrm{~b}$ ), and extending their range farther downstream is a management objective (Wang et al., 2002).

The model demonstrates that the temperature of Joos Creek is quite sensitive to changes in shade. The temperature difference for simulations of minimum shade (grazed pasture or crops with no riparian buffer) and maximum shade (forest) conditions was approximately $2.8^{\circ} \mathrm{C}$ at the downstream end of the reach (Figure 5). Current conditions are very similar to the minimum shade case (Figure 2b), suggesting 
that conversion of the riparian vegetation to forest could result in substantial cooling.

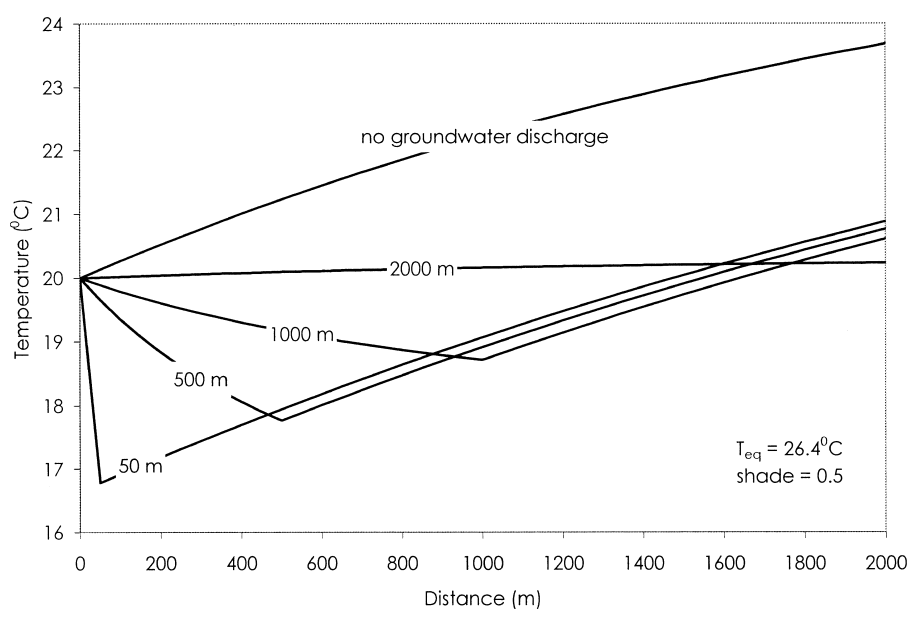

Figure 4. Simulated Impact of the Distribution of Ground Water Discharge. Upstream discharge (at distance $0 \mathrm{~m}$ ) is $0.05 \mathrm{~m}^{3} / \mathrm{s}$. Additional ground water discharge of $0.025 \mathrm{~m}^{3} / \mathrm{s}$ is uniformly distributed between $0 \mathrm{~m}$ and the distance indicated by labels on each curve; shorter distances indicate more concentrated ground water discharge. Temperature for no ground water discharge is shown for comparison.

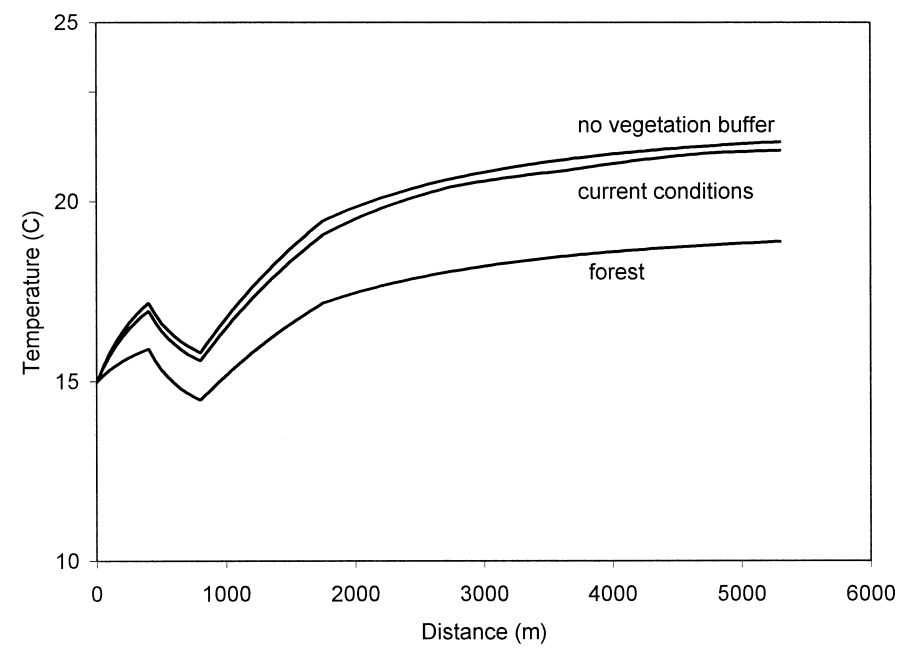

Figure 5. Sensitivity of Joos Creek Model to Changes in Shade From Streamside Vegetation.

However, changes in stream width that could accompany the addition of trees in the riparian zone have the potential to offset the benefit of the increased shade (Blann et al., 2001). Forested streams in the northeastern United States are up to 100 percent wider than those with grassy riparian zones (Allmendinger et al., 2000). This may be caused by increased streambank erosion where trees fall, deflecting current laterally and dislodging soil in the root zone. Qualitative field observations in the study area suggest that this may also be the case in the Midwest (Lyons et al., 2000).

The potential impact of increases in stream channel width was assessed by simulating forested conditions along the entire length of Joos Creek for three different channel conditions: current width and increases in width of 50 percent and 100 percent (Figure 6). A 50 percent increase in width negated the benefit of the addition of trees in the upper $1,700 \mathrm{~m}$, although the temperature at the downstream end of the reach was more than $1^{\circ} \mathrm{C}$ cooler than for current conditions. When the width was doubled, the headwater temperature was approximately $1^{\circ} \mathrm{C}$ greater than for current conditions, with no change in the downstream temperature. As shown in Figure 3, increases in width result in rapid warming in headwater reaches. However, shaded conditions lead to a lower equilibrium temperature (Table 1), and the stream stabilizes at a lower temperature farther downstream. This suggests that the benefit of converting streamside vegetation to trees increases with distance downstream.

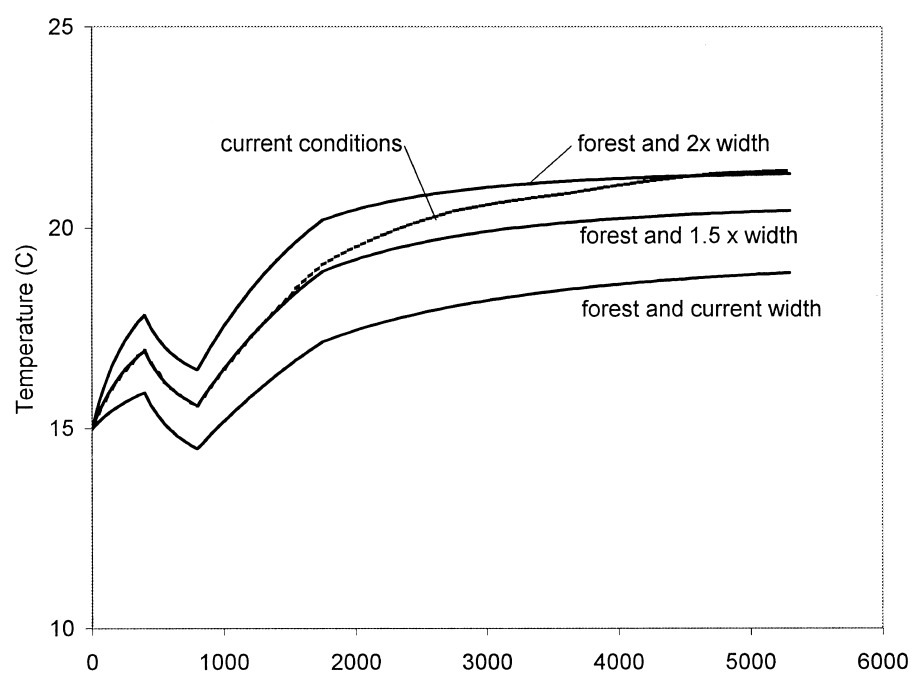

Figure 6. Sensitivity of Joos Creek Model to Changes in Stream Width. Forested conditions are compared with current vegetation (primarily grass).

Stream temperature is also sensitive to variations in base flow that may be caused by changes in climate or ground water recharge. Since the 1930s, seven-day low flows in this region have varied by as much as 50 percent of the present value (Gaffield, 2000). The impact of such changes in flow was simulated by changing the base flow input to the model by a uniform percentage along the length of the stream reach. 
The magnitude of the temperature impact is similar to that caused by changes in shade and stream width (Figure 7). Notice that temperature is more sensitive to decreases than increases in base flow. This underscores the importance of maintaining ground water recharge in these watersheds.

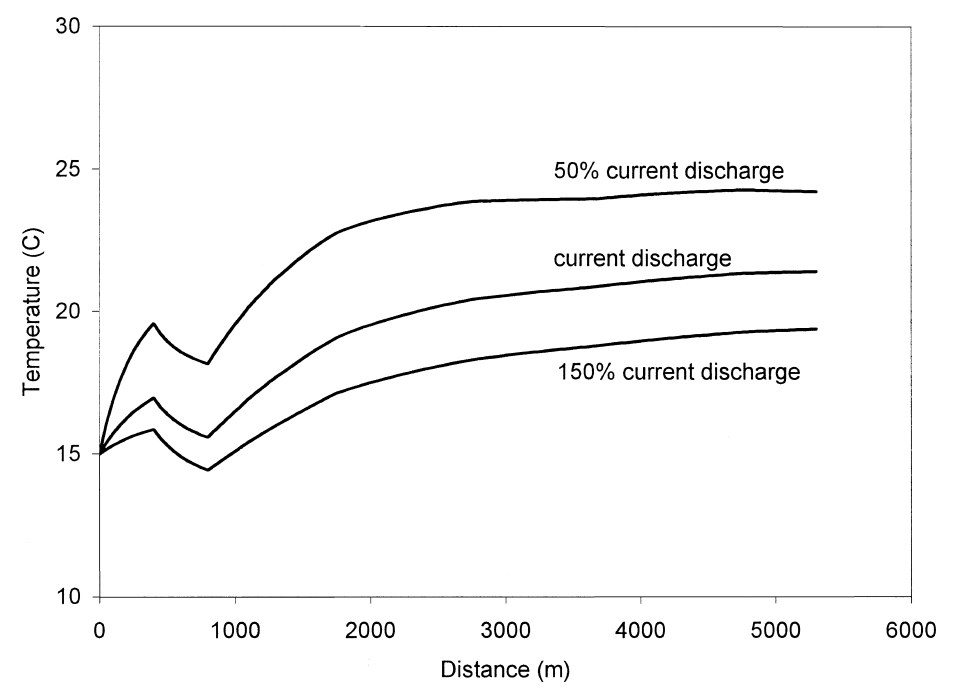

Figure 7. Sensitivity of Joos Creek Model to Changes in Stream Base Flow.

\section{SUMMARY AND CONCLUSIONS}

This adaptation of the SNTEMP model (Theuer et al., 1984) provides a simple tool to predict cold water stream temperature given complex patterns of ground water input, riparian shade, and channel width along the length of the stream. Stream temperature was demonstrated to be highly sensitive to the distribution of ground water input, which is controlled by climate, geology, and watershed land use. Springs are particularly important for providing thermal refuges for fish in extreme weather conditions. Riparian vegetation is also critical in maintaining stream temperature by providing shade and influencing channel morphology. For spring-fed streams, the model can predict how far downstream temperatures suitable for trout can be maintained under different management scenarios for watershed land use and riparian vegetation.

When applying the model, it is important to bear in mind its limitations. First, the model predicts daily mean temperature for the warmest period of summer, and the shade values used here are not appropriate for other seasons or for larger rivers. Vegetation type influences the amount of shading, and the amount of shade provided by any particular vegetation type decreases with stream width (Blann et al., 2001). When applying the model to different vegetation types, sizes of streams, or seasons, the shading and meteorological parameters need to be recalculated following the procedure in the Appendix. Second, assigning a single shade value to each vegetation type introduces some uncertainty by ignoring variability in shade within each vegetation category. The standard deviation of shade measurements for different types of riparian vegetation in southeastern Minnesota ranged from 5.8 percent to 21.7 percent (Blann et al., 2001). Figure 5 provides an indication of the sensitivity of the model to variations in shade. Last, this model does not simulate processes that have an important impact on stream temperature in other geomorphic settings, such as exchange of water in the hyporheic zone (Poole and Berman, 2001). Hyporheic exchange is unlikely to be significant in the study streams; minipiezometers installed in the streambed and computer simulations of ground water flow both indicate strong upwelling of ground water throughout the length of the channel (Gaffield et al., 1998).

In spite of these limitations, the model illustrates the importance of ground water in controlling the summer temperature of small Midwestern streams. Managing land use to maintain ground water recharge and stream base flow is important for maintaining suitable temperatures in cold water streams. Although there is a need for better understanding of the complex processes controlling stream temperature, models can provide useful information to improve watershed management decisions.

\section{APPENDIX A \\ ESTIMATION OF METEOROLOGICAL PARAMETERS}

To apply this model to a stream outside the Driftless Area or a different time period, it may be necessary to estimate new values for the parameters that represent meteorologic conditions, Teq and $\mathrm{H}$. Because these parameters depend on the degree of shading, new parameter values must be computed for each shade value used in the model.

Estimates for these parameters are based upon the energy budget of the stream. The net energy flux, $S_{n}$ $\left(\mathrm{W} / \mathrm{m}^{2}\right)$, between the stream and its environment is a function of water temperature, $\mathrm{T}\left({ }^{\circ} \mathrm{C}\right.$, and can be written

$$
\mathrm{S}_{\mathrm{n}}(\mathrm{T})=\mathrm{S}_{\mathrm{s}}+\mathrm{S}_{\mathrm{a}}+\mathrm{S}_{\mathrm{v}}+\mathrm{S}_{\mathrm{w}}+\mathrm{S}_{\mathrm{c}}+\mathrm{S}_{\mathrm{e}}+\mathrm{S}_{\mathrm{b}}
$$

where $\mathrm{S}_{\mathrm{S}}$ is the short wave solar radiation, $\mathrm{S}_{\mathrm{a}}$ is the atmospheric long wave radiation, $\mathrm{S}_{\mathrm{v}}$ is the vegetative 
long wave radiation, $\mathrm{S}_{\mathrm{w}}$ is the long wave radiation emitted by the water, $\mathrm{S}_{\mathrm{c}}$ is the convection in the air, $\mathrm{S}_{\mathrm{e}}$ is the evaporation, and $\mathrm{S}_{\mathrm{b}}$ is the streambed conduction.

Each of these energy budget components was estimated with the approximations used in the Stream Network Temperature Model (SNTEMP) developed by Theurer et al. (1984). Chapra (1997) presented similar approximations.

\section{Solar Radiation}

Short wave solar radiation reaching the stream is reduced by the fraction of sky blocked by shade, s, and the amount reflected by the water surface. The albedo of water, $\alpha_{\mathrm{S}}$ (dimensionless), represents the fraction of radiation that is reflected by the water surface, and had an assumed typical value of 0.06 . The solar radiation flux received by the stream, $\mathrm{S}_{\mathrm{s}}$ in $\mathrm{W} / \mathrm{m}^{2}$, is (Theurer et al., 1984)

$$
\mathrm{S}_{\mathrm{S}}=(1-\mathrm{s})\left(1-\alpha_{\mathrm{s}}\right) \mathrm{R}
$$

Solar radiation flux, $\mathrm{R}\left(\mathrm{W} / \mathrm{m}^{2}\right)$, was measured with pyronometers located in areas with full sun exposure. However, it is possible to estimate $R$ based on geographic location and time of year (Theurer et al., 1984).

\section{Atmospheric Long Wave Radiation}

The atmosphere emits radiation at a lower frequency (longer wavelength) than solar radiation, because it is much cooler than the sun. For long wave reflectivity, $\alpha_{\mathrm{L}}$ (dimensionless and assumed to be 0.03 ), atmospheric vapor pressure, e (mb), fractional cloud cover, $\mathrm{m}_{\mathrm{c}}$, air temperature, $\mathrm{T}_{\mathrm{a}}\left({ }^{\circ} \mathrm{C}\right)$, and Stefan-Boltzmann constant, $\sigma\left(5.67 \times 10^{-8} \mathrm{~W} / \mathrm{m}^{2} / \mathrm{C}^{4}\right)$, the long wave radiation flux received by the stream can be approximated by (Theurer et al., 1984)

$$
\begin{aligned}
\mathrm{S}_{\mathrm{a}}= & (1-\mathrm{s})\left(1-\alpha_{\mathrm{L}}\right) 10.03\left(0.53+0.065 \mathrm{e}^{0.5}\right) \\
& \left(1+0.4 \mathrm{~m}_{\mathrm{c}}\right) \sigma\left(\mathrm{T}_{\mathrm{a}}+273.16\right)^{4}
\end{aligned}
$$

\section{Vegetative Long Wave Radiation}

The stream also receives long wave radiation from vegetation, with the flux depending on the fraction of sky covered by vegetation, and its temperature and emissivity, $\varepsilon_{\mathrm{v}}$ (dimensionless). The temperature of the vegetation was assumed to be the same as the air temperature. The vegetative radiation flux can be approximated by (Theurer et al., 1984)

$$
\mathrm{S}_{\mathrm{v}}=\mathrm{s} \varepsilon_{\mathrm{v}} \sigma\left(\mathrm{T}_{\mathrm{a}}+273.16\right)^{4}
$$

\section{Long Wave Radiation Emitted by Stream}

The water in the stream loses energy through longwave radiation that it emits at a rate depending on its temperature. For water with emissivity, $\varepsilon_{\mathrm{w}}$ (dimensionless), and temperature, $\mathrm{T}\left({ }^{\circ} \mathrm{C}\right)$, this flux is approximately (Theurer et al., 1984)

$$
\mathrm{S}_{\mathrm{w}}=\varepsilon_{\mathrm{w}} \sigma(\mathrm{T}+273.16)^{4}
$$

\section{Convection}

Convective heat transfer between the air and the stream surface is a turbulent process depending on wind speed, $\mathrm{v}_{\mathrm{w}}(\mathrm{m} / \mathrm{s})$, atmospheric pressure, $\mathrm{P}_{\mathrm{a}}(\mathrm{mb})$, and the difference between the air and water temperatures. The convective heat flux is approximately (Theurer et al., 1984)

$$
\mathrm{S}_{\mathrm{c}}=\left(0.00375+0.0014 \mathrm{v}_{\mathrm{w}}\right) \mathrm{P}_{\mathrm{a}}\left(\mathrm{T}_{\mathrm{a}}-\mathrm{T}\right)
$$

\section{Evaporation}

The heat flux from evaporation at the stream surface depends on several meteorologic parameters and is difficult to estimate accurately. The following approximation was used for wind speed, $\mathrm{v}_{\mathrm{w}}$, and relative humidity, $\mathrm{R}_{\mathrm{h}}$ (Theurer et al., 1984)

$$
\mathrm{S}_{\mathrm{e}}=\left(40+15 \mathrm{v}_{\mathrm{w}}\right)\left(\mathrm{R}_{\mathrm{h}} 1.064^{\mathrm{T}} \mathrm{a}-1.064^{\mathrm{T}}\right)
$$

\section{Streambed Conduction}

The conductive heat flux between the streambed and water depends on the difference between the water temperature and the equilibrium soil temperature. At shallow depths, the soil temperature fluctuates with air temperature. As depth increases, these fluctuations are damped, and the soil temperature approaches equilibrium with the average air temperature. The depth, z (m), at which this occurs was estimated using the method described by Campbell and Norman (1997), using measured air temperature fluctuations and typical soil thermal properties. For soil 
with equilibrium temperature, $\mathrm{T}_{\mathrm{S}}\left({ }^{\circ} \mathrm{C}\right)$, and thermal conductivity, $\mathrm{K}_{\mathrm{T}}\left(\mathrm{W} / \mathrm{m} /{ }^{\circ} \mathrm{C}\right)$, the conductive flux through the streambed is

$$
\mathrm{S}_{\mathrm{b}}=\mathrm{K}_{\mathrm{T}}\left(\frac{\mathrm{T}_{\mathrm{S}}-\mathrm{T}}{\mathrm{z}}\right)
$$

\section{Parameter Estimation}

The equilibrium temperature, $\mathrm{T}_{\mathrm{eq}}$, is the temperature for which the net flux is zero. After substituting Equations (A2) through (A8) into Equation (A1), $\mathrm{T}_{\mathrm{eq}}$ is estimated by trial and error. This is most efficiently performed in a computer program, such as a spreadsheet that has an equation solving function.

Inspection of Equation (1) reveals that $\mathrm{H}$ can be found by taking the first derivative of Equation (A1) evaluated at $\mathrm{T}_{\mathrm{eq}}$.

$$
\mathrm{H}=\left|\frac{\mathrm{d} \mathrm{S}_{\mathrm{n}}}{\mathrm{dT}}\right|_{\mathrm{T}=\mathrm{T}_{\mathrm{eq}}} /\left(\rho \mathrm{c}_{\mathrm{p}}\right)
$$

After substituting the expressions for heat flux components into Equation (A1), differentiating, and evaluating the derivative at $\mathrm{T}_{\mathrm{eq}}$, the result can be substituted into Equation (A9) to determine the value for $\mathrm{H}$.

\section{ACKNOWLEDGMENTS}

The authors thank Kenneth Bradbury and John Lyons for their insightful discussion during the early part of the study. Funding for this project was partially provided by Trout Unlimited. L. Wang was also funded by grants provided by the Wisconsin Department of Natural Resources, Bureau of Watershed Management and Bureau of Integrated Science Services Fish and Habitat Research. The authors also thank four anonymous reviewers for their comments.

\section{LITERATURE CITED}

Allmendinger, N.E., J.E. Pizzuto, T.E. Johnson, and W.C. Hession, 2000. The Influence of Riparian Vegetation on Channel Morphology and Lateral Migration. EOS, Transactions of the American Geophysical Union 2000 Spring Meeting: S254.

Andradottir, H.O. and H.M. Nepf, 2000a. Thermal Mediation by Littoral Wetlands and Impact on Lake Intrusion Depth. Water Resources Research 36(3):725-735.

Andradottir, H.O. and H.M. Nepf, 2000b. Thermal Mediation in a Natural Littoral Wetland: Measurements and Modeling.Water Resources Research 36(10):2937-2946.
Bartholow, J.M., 2002. SSTEMP for Windows: The Stream Segment Temperature Model (Version 2.0). USGS Computer Model and Documentation. Available at http://www.fort.usgs.gov/. Accessed in May 2003.

Becker, G.C., 1983. Fishes of Wisconsin. University of Wisconsin Press, Madison, Wisconsin.

Blann, K., J.F. Nerbonne, and B. Vondracek, 2001. Relationship of Riparian Buffer Type to Water Temperature in the Driftless Area Ecoregion of Minnesota. North American Journal of Fisheries Management 22(2):441-451.

Bowlby, J.N. and J.C. Roff, 1986. Trout Biomass and Habitat Relationships in Southern Ontario Streams. Transactions of the American Fisheries Society 115(4):503-514.

Buchanan, T.J. and W.P. Somers, 1969. Discharge Measurements at Gaging Stations. Techniques of Water-Resources Investigations of the U.S. Geological Survey 3(A8). U.S. Geological Survey, Alexandria, Virginia.

Campbell, G.S. and J.M. Norman, 1997. An Introduction to Environmental Biophysics. Springer-Verlag, New York, New York.

Chapra, S.C., 1997. Surface Water-Quality Modeling. McGraw-Hill, Madison, Wisconsin.

Constantz, J., 1998. Interaction Between Stream Temperature, Streamflow and Ground Water Exchanges in Alpine Streams. Water Resources Research 34(7):1609-1615.

Delay, W.H. and J. Seaders, 1966. Predicting Temperatures in Rivers and Reservoirs. Journal of the American Society of Civil Engineers Sanitation Engineering Division 92:115-134.

Diana, J.S., 1995. Biology and Ecology of Fishes. Cooper Publishing Group, Carmel, Indiana.

Domenico, P.A. and F.W. Schwartz, 1990. Physical and Chemical Hydrogeology. John Wiley and Sons, New York, New York.

Dunne, T. and L.B. Leopold, 1978. Water in Environmental Planning. W.H. Freeman and Company, New York, New York.

Field, S.J. and D.J. Graczyk, 1990. Hydrology, Aquatic Macrophytes, and Water Quality of Black Earth Creek and Its Tributaries, Dane County, Wisconsin. Water Resources Investigations Report 89-4089, U.S. Geological Survey, Madison, Wisconsin.

Fischer, H.B., E.J. List, R.C.Y. Koh, J. Imberger, and N.H. Brooks, 1979. Mixing in Inland and Coastal Waters. Academic Press, New York, New York.

Gaffield, S.J., 2000. Evaluation of the Controls of Summer Stream Temperature in the Driftless Area of Southwestern Wisconsin. $\mathrm{Ph} . D$. Dissertation, University of Wisconsin-Madison, Bell and Howell Information and Learning Microfilm No. 9996802.

Gaffield, S.J., K.R. Bradbury, and K.W. Potter, 1998. Hydrologic Assessment of the Kickapoo Watershed, Southwestern Wisconsin. Open File Report 1998-8, Wisconsin Geological and Natural History Survey, Madison, Wisconsin.

Johnson, W.C., 1976. The Impact of Environmental Change on Fluvial Systems: Kickapoo River. Ph.D. Dissertation, University of Wisconsin-Madison, Bell and Howell Information and Learning Microfilm No. 7708791.

Kent, C.A., 1999. The Influence of Changes in Land Cover and Agricultural Land Management Practices on Baseflow in Southwest Wisconsin, 1969-1998. Ph.D. Dissertation, University of Wisconsin-Madison, Bell and Howell Information and Learning Microfilm No. 9927277.

Lowney, C.L., 2000. Stream Temperature Variation in Regulated Rivers: Evidence for a Spatial Pattern in Daily Minimum and Maximum Magnitudes. Water Resources Research 36(10):29472955.

Lyons, J., S.W. Trimble, and L.K. Paine, 2000. Grass Versus Trees: Management of Riparian Areas to Benefit Streams of Central North America. Journal of the American Water Resources Association (JAWRA) 36(4):919-930. 
McRae, G. and C.J. Edwards, 1994. Thermal Characteristics of Wisconsin Headwater Streams Occupied by Beaver: Implications for Brook Trout Habitat. Transactions of the American Fisheries Society 123:641-656.

Meisner, J.D., 1990. Potential Loss of Thermal Habitat for Brook Trout, Due to Climatic Warming, in Two Southern Ontario Streams. Transactions of the American Fisheries Society 119:282-291.

Meisner, J.D., J.S. Rosenfeld, and H.A. Regier, 1988. The Role of Ground Water in the Impact of Climate Warming on Stream Salmonines. Fisheries 13(3):2-8.

Poff, N.L. and J.D. Allan, 1995. Functional Organization of Stream Fish Assemblages in Relation to Hydrological Variability. Ecology 76(2):606-627.

Poole, G.C. and C.H. Berman, 2001. An Ecological Perspective on In-Stream Temperature: Natural Heat Dynamics and Mechanisms of Human-Caused Thermal Degradation. Environmental Management 27(6):787-802.

Potter, K.W., 1991. Hydrological Impacts of Changing Land Management Practices in a Moderately Sized Agricultural Catchment. Water Resources Research 27(5):845-855.

Potter, K.W., 2001. A Simple Method for Estimating Base Flow at Ungaged Locations. Journal of the American Water Resources Association (JAWRA) 37(1):177-184.

Potter, K.W. and S.J. Gaffield, 2001. Watershed Assessment With Synoptic Base Flow Surveys. In: Geomorphic Processes and Riverine Habitat, J. Dorava, D. Montgomery, B. Palcsak, and F. Fitzpatrick (Editors). Water Science and Application Series Monograph 4, American Geophysical Union, Washington, D.C., pp.19-25.

Sampson, N.R., 1981. Farmland or Wasteland: A Time to Choose. Rodale Press, Emmaus, Pennsylvania.

Scott, W.E. and N.H. Hoveland, 1951. Report to the People of Wisconsin on Cover Destruction, Habitat Improvement and Watershed Problems in the State in 1950. Wisconsin Conservation Bulletin 16(2):3-78.

Seelbach, P.W. and M.J. Wiley, 1997. Overview of the Michigan Rivers Inventory (MRI) Project. Fisheries Technical Report 97-3, Michigan Department of Natural Resources, Ann Arbor, Michigan.

Seelbach, P.W., M.J. Wiley, J.C. Kotanchik and M.E. Baker, 1997. A Landscape-Based Ecological Classification System for River Valley Segments in Lower Michigan. Fisheries Technical Report 2036, Michigan Department of Natural Resources, Ann Arbor, Michigan.

Sinokrot, B.A. and H.G. Stefan, 1993. Stream Temperature Dynamics: Measurement and Modeling. Water Resources Research 29(7):2299-2312.

Theurer, F.D., K.A. Voos, and W.J. Miller, 1984. Instream Water Temperature Model. Instream Flow Information Paper 16, U.S. Fish and Wildlife Service, Washington, D.C.

Trimble, S.W. and S.W. Lund, 1982. Soil Conservation and the Reduction of Erosion and Sedimentation in the Coon Creek Basin, Wisconsin. Professional Paper 1234, U.S. Geological Survey, Alexandria, Virginia.

Wang, L., J. Lyons, and P. Kanehl, 2002. Effects of Watershed Best Management Practices on Habitat and Fish in Wisconsin Streams. Journal of the American Water Resources Association (JAWRA) 38(3):663-680.

Young, H.L., 1992. Hydrogeology of the Cambrian-Ordovician Aquifer System in the Northern Midwest, United States. Professional Paper 1405-B, U.S. Geological Survey, Reston, Virginia.

Younus, M., M. Hondzo, and B.A. Engel, 2000. Stream Temperature Dynamics in Upland Agricultural Watersheds. Journal of Environmental Engineering 126(6):518-526.
Zaporozec, A. and R.D. Cotter, 1985. Major Ground-Water Units of Wisconsin. Wisconsin Geological and Natural History Survey, Madison, Wisconsin. 